\title{
MICROSTRUCTURAL CHARACTERIZATION AND WEAR BEHAVIOR OF WC-COCr COATING ON AZ91 MAGNESIUM ALLOY
}

\author{
${ }^{1}$ Martin BUCHTÍK, ${ }^{1}$ Jiří MÁSILKO, ${ }^{2}$ Ondřej VYKLICKÝ, ${ }^{2} J a n$ FILIPENSKÝ, \\ ${ }^{1}$ Jaromír WASSERBAUER, ${ }^{1}$ Petr PTÁČEK
}

\author{
${ }^{1}$ Materials Research Centre, Faculty of Chemistry, Brno University of Technology, Czech Republic, EU, \\ xcbuchtik@fch.vutbr.cz \\ ${ }^{2}$ Plasmametal, spol. s.r.o., Brno, Czech Republic, EU
}

https://doi.org/10.37904/metal.2019.730

\begin{abstract}
This paper includes the microstructural and wear characterization of WC-10Co4Cr coating on AZ91 magnesium alloy. Using the scanning electron microscopy and X-ray diffraction analysis it was determined that the microstructure was formed by WC particles, $\mathrm{CoCr}$ matrix, present $\mathrm{Co}_{3} \mathrm{~W}_{3} \mathrm{C}$ mixed carbide, $\mathrm{W}_{2} \mathrm{C}$, and free carbon. The presence of $\mathrm{W}_{2} \mathrm{C}$ and free carbon indicates the partial decarburization during the spraying process. The microhardness of HVOF-sprayed coating was $1480 \pm 80$ HV 0.05 , which is approximately $20 \times$ higher when compared to AZ91 alloy. The friction coefficient values with the subsequent weight loss of the coating and magnesium substrate were determined. It has been proven that HVOF-sprayed WC-CoCr coating can protect the magnesium substrate from the wear.
\end{abstract}

Keywords: WC-CoCr, HVOF, AZ91 alloy, microstructure, wear

\section{INTRODUCTION}

Magnesium alloys are very attractive materials and suitable alternative to other lightweight aluminum-based constructional materials due to their low density, high strength to weight ratio and other many advantages [1-3]. Magnesium alloys are a potential material for the automotive and aircraft industry. However, their application is limited due to undesirable properties, like poor corrosion and the tribological resistance [4-5]. To improve their usage and surface properties, a wide range of corrosive and wear resistant coatings and methods were developed [4]. Thermally sprayed coatings seem to be as an appropriate solution of these disadvantages. Example, WC-based, thermally sprayed coatings have excellent tribological properties and can improve the service life of machine components [6]. HVOF-sprayed WC-CoCr coatings are designed to have optional properties of WC non-oxide ceramic (hardness, wear resistance) and metal $\mathrm{CoCr}$ matrix (mostly plastic properties) [7]. WC-Co and WC-CoCr coatings are used for applications where wear and erosion resistance are needed [7-8]. These cermet coatings are also characterized by higher hardness, lower toughness, lower porosity and superior adhesion to the substrate. The application of these coatings can be found in the field, where is too much friction such as gas turbines, aeronautic or automotive components, for example, automotive engines (e.g. light magnesium engine block with wear resistant coating in the cylinder bore) [7-9]. This paper deals with the characterization of HVOF-sprayed WC-CoCr coatings on cast AZ91D magnesium alloy. It includes the study of the microstructure and the phase composition of the coating. Furthermore, this study deals with the mechanical and wear properties during the dry sliding wear test.

\section{EXPERIMENTAL MATERIALS AND METHODS}

As-cast AZ91 magnesium alloy with dimensions $100 \times 100 \times 7 \mathrm{~mm}$ was used as a substrate. The elemental composition (wt. \%) of the AZ91 substrate determined using the Glow-Discharge Optical Emission Spectroscopy (GDOES) Spectrumat GDS 750 (Spectruma Analytik GmbH, Hof, Germany) is Al: 8.80, Zn: $0.81, \mathrm{Mn}: 0.32$, Si: 0.01, Fe: 0.004, Mg: Balance. Before the coating deposition, the surface of the magnesium 
alloy was corundum blasted (brown corundum F36, $0.6 \mathrm{~mm}$ ). Agglomerated and sintered $\mathrm{WC}-10 \mathrm{Co} 4 \mathrm{Cr}$ (WOKA 3652 FC, Oerlikon) with the nominal size distribution of - $45 \pm 15 \mu \mathrm{m}$ was used as a feedstock powder. The elemental composition (wt. \%) of the WC-CoCr feedstock powder is Co: 8.5-11.5, Cr: 3.4-4.6, C (total): 4.8-5.6, Fe: max. 0.2, W: Balance. The deposition of WC-CoCr coating was performed by commercially available HVOF JP5000 spraying system.

Performed analysis of used feedstock WC-CoCr powder and the sprayed coating was obtained using Zeiss EVO LS-10 (Carl Zeiss Ltd., Cambridge, UK) scanning electron microscope (SEM) equipped with Oxford Instruments Xmax $80 \mathrm{~mm}^{2}$ detector (Oxford Instruments plc, Abingdon, UK) energy-dispersive spectrometer (EDS) and JEOL JSM-7600F (JEOL) Field-Emission Scanning Electron Microscope (FESEM). The phase composition of the powder and coating was gained using Empyrean (Panalytical) X-Ray diffraction spectrometer with Cu-anode $(\lambda \mathrm{Ka} 1=0.15406 \mathrm{~nm}, \lambda \mathrm{Ka} 2=0.15444 \mathrm{~nm})$ at room temperature. The hardness of as-sprayed coating was measured on polished cross-cuts by Vickers method under the applied load of $50 \mathrm{~g}$ with duration of $10 \mathrm{sec}$ according to the standard ASTM E384. The hardness was measured over the entire thickness of the sprayed coating. For the determination of tribological properties, the area with dimensions $50 \times 50 \mathrm{~mm}$ was cut off from the original samples with dimensions $100 \times 100 \times 7 \mathrm{~mm}$. The surface of the cut was ground and polished up to $1 \mu \mathrm{m}$ using diamond pastes to achieve the surface roughness $R_{a} \sim 0.05 \mu \mathrm{m}$. Wear test was performed on the universal tribometer Bruker UMT Tribolab (Bruker) by the ball-on-plate method with WC-12Co counter-ball $(7.5 \mathrm{~mm}$ in diameter) under $30 \mathrm{~N}$ at room temperature. The overall sliding distance was $450 \mathrm{~m}$ at $1800 \mathrm{~s}$ with frequency $5 \mathrm{~Hz}$.

\section{RESULTS AND DISCUSSION}

As shown in Figure 1a, WC-CoCr powder particles exhibit the spherical morphology which is typical for agglomerated and sintered materials with some degree of porosity. It is evident that in the case of some particles, the open pores are visible in the surface. Pores were present from the manufacturing process [7-9]. From the perpendicular cut of WC-CoCr particle (Figure 1b) a porous microstructure with small WC particles can be observed. WC particles appear as bright areas. These WC grains have an approximate size of 0.5 $2 \mu \mathrm{m}$. The distribution of WC grains in the WC-CoCr powder is not completely homogeneous. Light gray areas formed by $\mathrm{Co}$ and dark gray areas formed by $\mathrm{Cr}$ (or $\mathrm{CoCr}$ ) are unevenly distributed between WC particles. Both of these gray phases of $\mathrm{CoCr}$ form a matrix with a certain amount of dissolved W [10]. The black areas are pores. According to Bolelli et al. [11], W is in the matrix in the form of fine WC precipitates or in the form of mixed carbides. Frisk and Markström [12] reported that the composition of this carbides is $(\mathrm{Co}, \mathrm{Cr}, \mathrm{W})_{7} \mathrm{C}_{3}$, which is formed above the $\mathrm{Cr}$ solubility limit in the $\mathrm{CoCr}$ matrix at high $\mathrm{C}$ content. Some authors [13-15] admit the existence of $\eta-\mathrm{M}_{6} \mathrm{C}\left(\mathrm{Co}_{2-3} \mathrm{~W}_{4-3} \mathrm{C}\right), \mathrm{M}_{12} \mathrm{C}\left(\mathrm{Co}_{6} \mathrm{~W}_{6} \mathrm{C}\right)$ carbides and $(\mathrm{W}, \mathrm{C}, \mathrm{Co}) \times$ nanocrystalline supersaturated solid solutions.
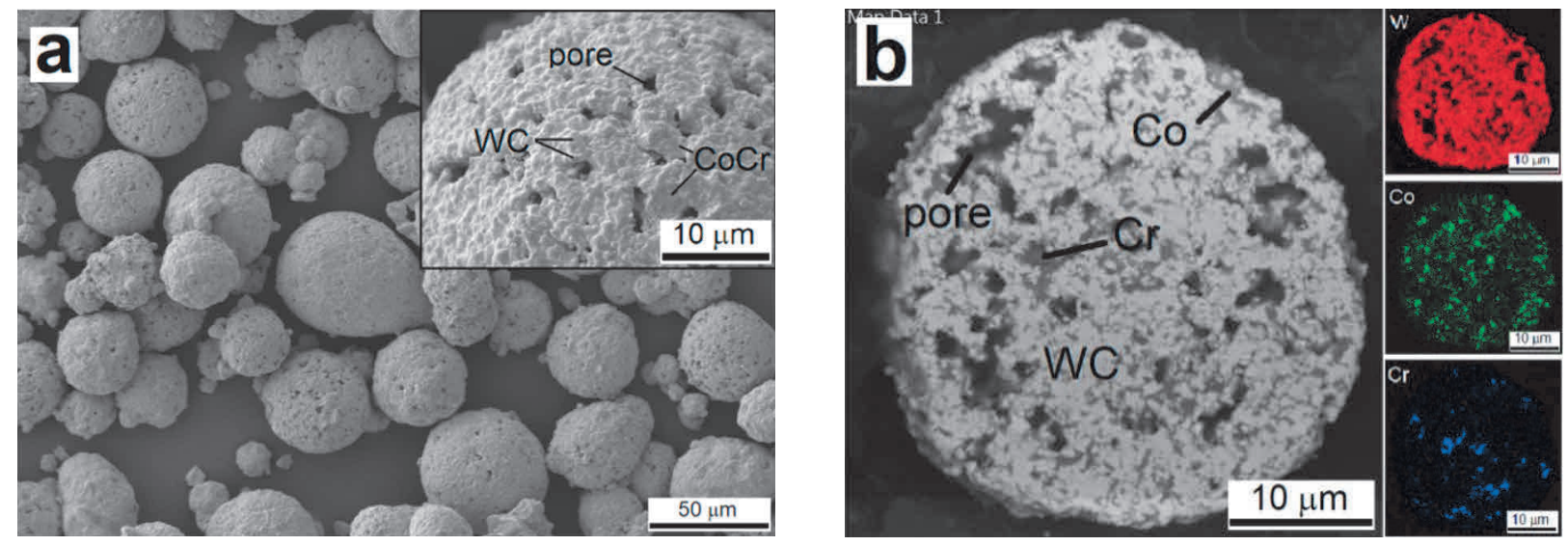

Figure 1 WC-10Co4Cr powder, a) Surface morphology, b) Perpendicular cut analysis 
The microstructure of HVOF WC-CoCr coating on AZ91 magnesium alloy is shown in Figure 2. The average coating thickness was approximately $400 \mu \mathrm{m}$. The evenly sprayed coating does not show the locally increased porosity, macrocracks or oxidized bands. The porosity of the coating was determined on $4.6 \%$. Between the WC-CoCr coating and the AZ91 magnesium substrate, no oxide interlayer was observed. As shown in Figure 2, WC particles and $\mathrm{CoCr}$ binder were clearly recognizable in the coating. The CoCr matrix in the coating was not completely homogeneously distributed. It was possible to observe large matrix areas which have an adverse effect on the local hardness and abrasion resistance of the coating. The hardness of the coating was determined on $1480 \pm 80 \mathrm{HV} 0.05$. The hardness of AZ91 magnesium alloy was determined on $71 \pm 3$ HV 0.05 .

Both micro-sized WC particles and sub-micron particles were represented in the coating (Figure 2b). As shown in Figure $\mathbf{2 b}$, finer and sub-micron WC grains have rounded edges. This is due to the decarburization and dissolution of the WC in the matrix under elevated temperature [11,13]. The decomposition of WC during the spraying is possible to observe on the XRD pattern (Figure 3) when $\mathrm{W}_{2} \mathrm{C}$ and free carbon are formed (Equation 1). Irregular $\mathrm{W}_{2} \mathrm{C}$ particles surround the WC grains (Figure 2b). The literature [11] states that in the case of WC-10Co4Cr coatings, the XRD diffraction of $\mathrm{W}_{2} \mathrm{C}$ is shifted from the theoretical position $2 \theta \approx 39.57^{\circ}$ to $39.94^{\circ}$ due to partial substitution of $\mathrm{Cr}$ in the $\mathrm{W}_{2} \mathrm{C}$ lattice to form $(\mathrm{W}, \mathrm{Cr})_{2} \mathrm{C}$.
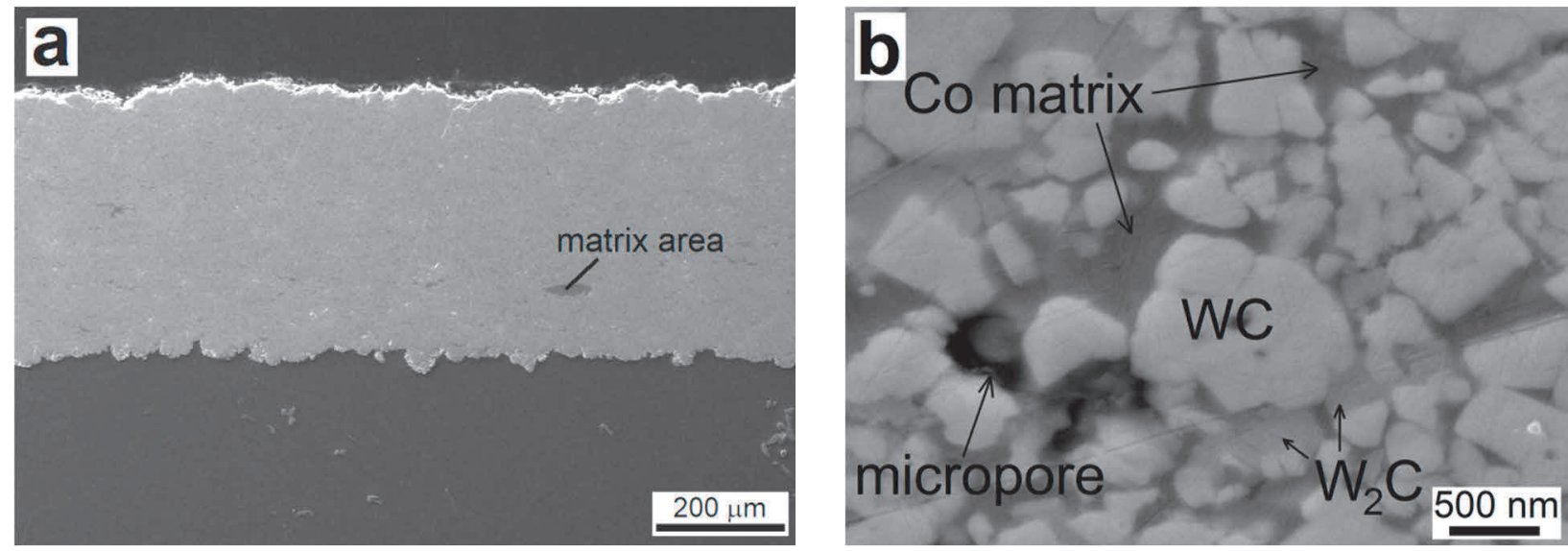

Figure 2 Microstructural analysis of deposited coating, a) Cross-cut, b) Microstructure at higher magnification

Due to the higher temperature, the CoCr matrix melted and metallurgical reaction between matrix and WC occurred to form mixed carbides during the powder production and during the HVOF spraying (Equation 2 and 3) [16]. From Figure 3, it is evident that despite the partial WC decomposition, the intensity of WC is still the highest. When compared to the powder, the decrease of WC intensity was observed after spraying (Figure 3). It is due to the decomposition, decarburization and the increase in lattice disorder as a result of particle impact on the substrate surface during the spraying [11]. Figure 3 also shows that the $\mathrm{M}_{6} \mathrm{C}$ phase intensity decreases. This effect is due to the decarburization and the formation of $\mathrm{W}_{2} \mathrm{C}$ phase.

$W C \rightarrow W_{2} C+C$

$3 \mathrm{Co}+3 \mathrm{WC}+\mathrm{O}_{2} \rightarrow \mathrm{Co}_{3} \mathrm{~W}_{3} \mathrm{C}+2 \mathrm{CO}$

$12 \mathrm{Co}+12 \mathrm{WC}+5 \mathrm{O}_{2} \rightarrow 2 \mathrm{Co}_{6} \mathrm{~W}_{6} \mathrm{C}+10 \mathrm{CO}$ 


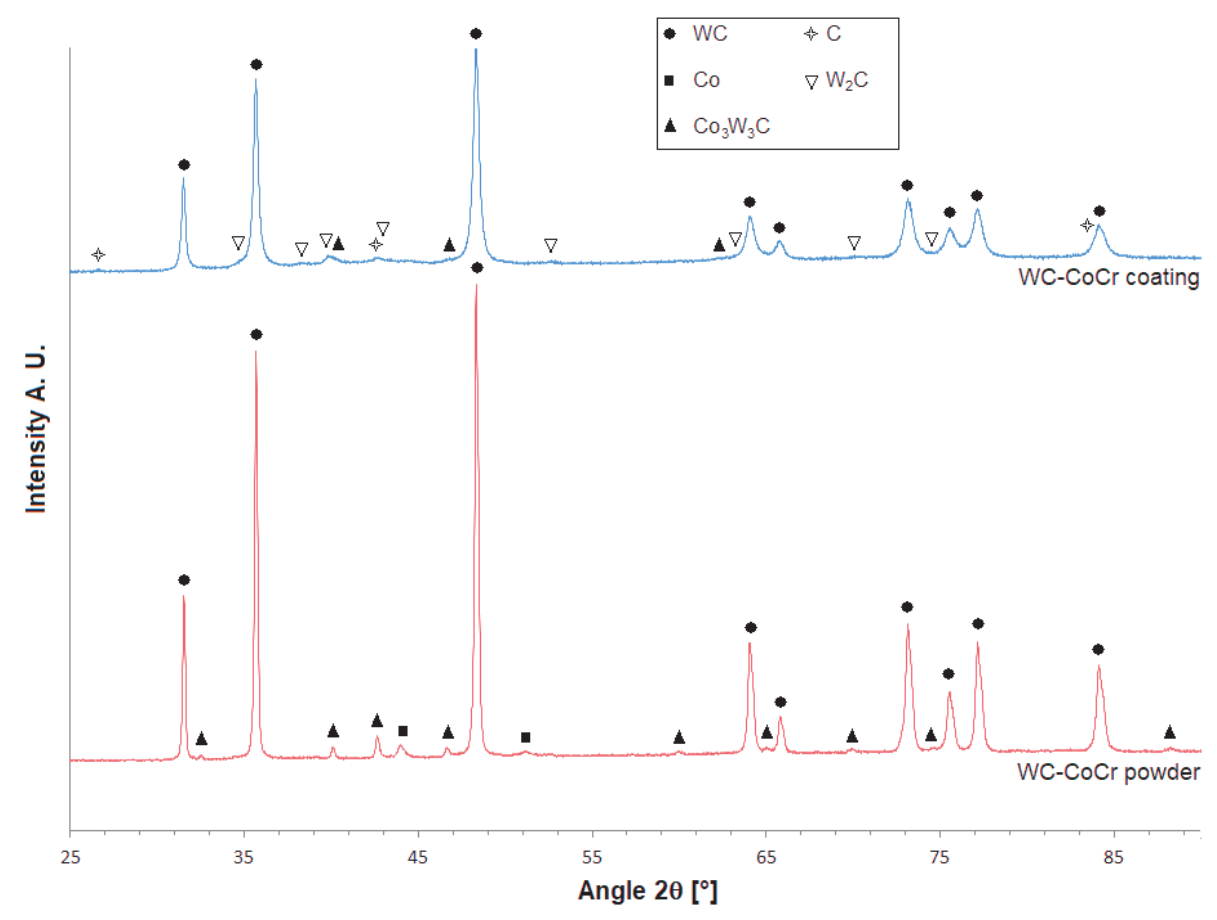

Figure 3 XRD pattern of WC-CoCr coating and feedstock powder

Results of dry sliding wear test are shown in Figure 4. In the case of WC-CoCr coating, the coefficient of friction (COF) increased to 0.8 after $\sim 300 \mathrm{~s}$ and then slightly increased up to the value of 0.9 . The COF of uncoated AZ91 was significantly lower, 0.2 to 0.25 . However, the higher wear rate and weight loss were observed for plain AZ91 alloy. The weight loss for uncoated magnesium alloy was determined on $120 \mathrm{mg}$ and the weight loss for AZ91 alloy with WC-CoCr coating was determined on $6.6 \mathrm{mg}$. As observed from Figure 4a, due to the sliding of WC-12Co counter-ball on the surface, the preferential removing of the deformed $\mathrm{CoCr}$ matrix surrounding the WC particles occurred during the wear test [9]. It results in the increase in the surface roughness, the formation of cracks (A) and pull-out of grains (B) [9]. The oscillation and the severe wear were more apparent for plain AZ91 alloy (Figure 4b). Literature [17] stated that $\alpha-M g / \beta-M g{ }_{17} \mathrm{Al}_{12}$ phase interface served as a source of cracks (A). Formed cracks and the plasticity loss lead to the spalling of surface and the formation of bigger spalling pits (B) and delamination (C) (Figure 4b). During the friction and wear, the large amount of friction heat is produced which results to the heating and oxidation of the surface [18]. Moreover, $\beta$ $\mathrm{Mg}_{17} \mathrm{Al}_{12}$ phase has a poor thermal stability, so it has no significant strengthening or pinning effect $[1,17]$.
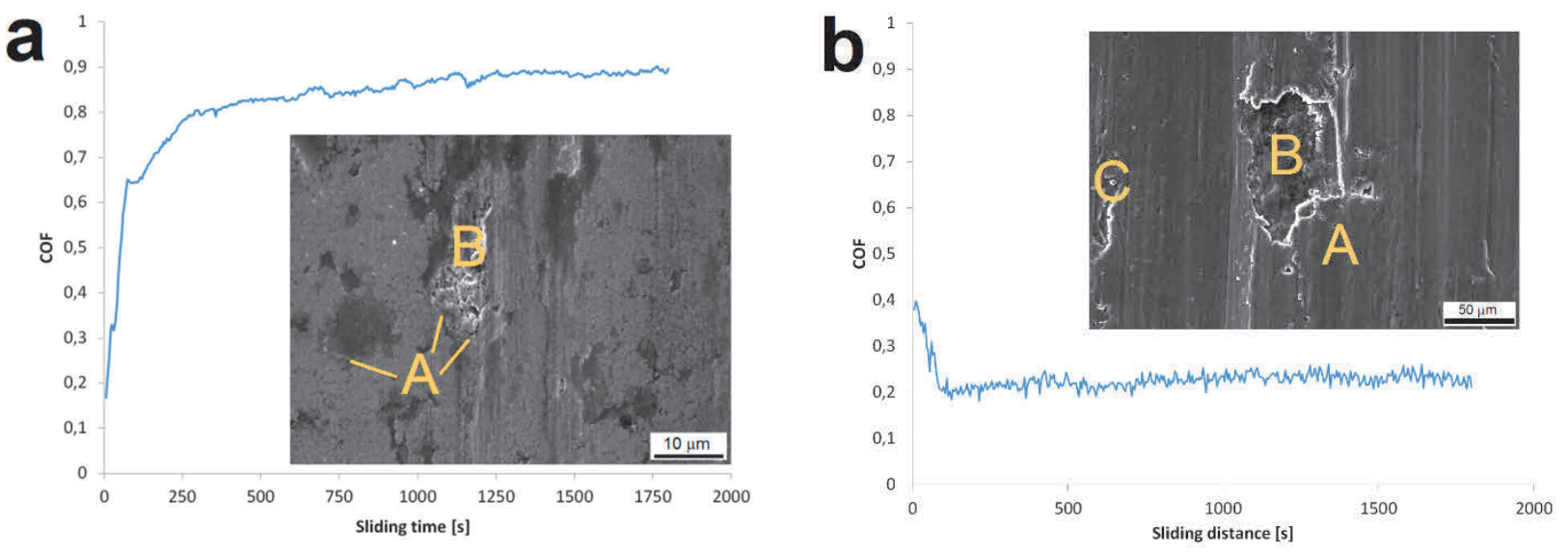

Figure 4 Results of the wear test, a) WC-CoCr coating, b) Uncoated AZ91 alloy 


\section{CONCLUSION}

- HVOF sprayed WC-10Co4Cr coatings on AZ91 magnesium alloy with the thickness approximately $400 \mu \mathrm{m}$ have the microhardness of $1480 \pm 80 \mathrm{HV} 0.05$, meanwhile, the microhardness of AZ91 alloy was $71 \pm 3 \mathrm{HV} 0.05$.

- $\quad$ No oxide interlayer was observed in the coating/substrate interface

- Comparing the powder and coating microstructure, it was determined that after the deposition process, the WC intensity decreased due to lattice disorder during the spraying and the $\mathrm{Co}_{3} \mathrm{~W}_{3} \mathrm{C}$ mixed carbide intensity decreased too. On the other hand, the presence of $\mathrm{W}_{2} \mathrm{C}$ and $\mathrm{C}$ was observed after the spraying as a result of decarburization.

- $\quad$ The value of COF for the coating increased when compared to AZ91 substrate, but there was a decrease in weight loss where uncoated AZ91alloy was subjected to severe wear.

\section{ACKNOWLEDGEMENTS}

This work was supported by project Nr. L01211, Materials Research Centre at FCH BUTSustainability and Development (National Programme for Sustainability I, Ministry of Education, Youth and Sports).

\section{REFERENCES}

[1] FRIEDRICH, Horst E. and MORDIKE, L. Barry. Magnesium technology: metallurgy, design data, applications. 1st ed. Berlin: Springer-Verlag Berlin Heidelberg, 2006. p. 677.

[2] DRÁPALA, J. Hořčík, jeho slitiny a binární systémy hořčík - př́měs: Magnesium, its alloya and Mg-admixture binary systems. 1st. ed. Ostrava: Vysoká škola báňská - Technická univerzita, 2004. p. 172.

[3] FAN, X., LIU, Y., XU, Z., WANG, Y., ZOU, B., GU, L., WANG, CH., CHEN, X., KHAN, Z. S., YANG, D. and CAO, L. Preparation and Characterization of 8YSZ Thermal Barrier Coatings on Rare Earth-Magnesium Alloy. Journal of Thermal Spray Technology. 2011, vol. 20, no. 4, pp. 948-957.

[4] OKADA, H., UEMATSU, Y. and TOKAJI, K. Fatigue behaviour in AZ80A magnesium alloy with DLC/thermally splayed WC-12Co hybrid coating. Procedia Engineering. 2010, vol. 2, no. 1, pp. 283-290.

[5] SONG, G. L. Corrosion of magnesium alloys. 1st ed. Cambridge: Woodhead Publishing, 2011. P. 656.

[6] PARCO, M., ZHAO, L., ZWICK, J., BOBZIN, K. and LUGSCHEIDER, E. Investigation of HVOF spraying on magnesium alloys. Surface and Coatings Technology. 2006, vol. 201, no. 6, pp. 3269-3274.

[7] FAUCHAIS, Pierre L., HEBERLEIN, Joachim V. R. and BOULOS, Maher. Thermal Spray Fundamentals: From Powder to Part. 1st ed. New York: Springer US, 2014, p. 1566.

[8] ESPALLARGAS, Nuria. Future Development of Thermal Spray Coatings: Types, Designs, Manufacture and Applications. Cambridge: Woodhead Publishing, 2015, p. 300.

[9] LIU, Y., LIU, W., MA, Y., MENG, S., LIU, C., LONG, L. and TANG, S. A comparative study on wear and corrosion behaviour of HVOF- and HVAF-sprayed WC-10Co-4Cr coatings. Surface Engineering. 2017, vol. 33, no. 1, pp. 63-71.

[10] NAHA, D., CHATTERJEE, S., GHOSH, M., MAJUMDAR, J. D. and MAJUMDAR, A. HVOF Sprayed WC-Cocr Coating on Mild Steel: Microstructure and Wear Evaluation. Journal of Applied Physics. 2016, vol. 8, no. 1, pp. 47-56.

[11] BOLELLI, G., BERGER, L.-M., BÖRNER, T., KOIVULUOTO, H., LUSVARGHI, L., LYPHOUT, C., MARKOCSAN, N., MATIKAINEN, V., NYLÉN, P., SASSATELLI, P., TRACHE, R. and VUORISTO, P. Tribology of HVOF- and HVAF-sprayed WC-10Co4Cr hardmetal coatings: A comparative assessment. Surface and Coatings Technology. 2015, vol. 265, pp. 125-144.

[12] FRISK, K. and MARKSTRÖM, A. Effect of $\mathrm{Cr}$ and $\mathrm{V}$ on phase equilibria in Co-WC based hardmetals. International Journal of Materials Research. 2008, vol. 105, no. 6, pp. 557-565. 
[13] BERGER, L.-M., ETTMAYER, P., VUORISTO, P., MÄNTYLÄ, T. and KUNERT, W. Microstructure and properties of WC-10\%Co-4\% Cr spray powders and coatings: Part 1. Powder characterization. Journal of Thermal Spray Technology. 2001, vol. 10, no. 2, pp. 311-325.

[14] SCHWETZKE, R. and KREYE, H. Microstructure and properties of tungsten carbide coatings sprayed with various high-velocity oxygen fuel spray systems. Journal of Thermal Spray Technology. 1999, vol. 8, no. 3, pp. 433-439.

[15] UPADHYAYA, Gopal S. Cemented tungsten carbides: production, properties, and testing. 1st. ed. William Andrew, Elsevier, 1998, p. 420.

[16] GUILEMANY, J. M., DOSTA, S., NIN, J. and MIGUEL, J. R. Study of the Properties of WC-Co Nanostructured Coatings Sprayed by High-Velocity Oxyfuel. Journal of Thermal Spray Technology. 2005, vol. 14, no. 3, pp. 405413.

[17] CHEN, Q., ZHAO, Z., ZHU, Q., WANG, G. and TAO, K. Cerium Addition Improved the Dry Sliding Wear Resistance of Surface Welding AZ91 Alloy. Materials. 2018, vol. 11, no. 2, pp. 1-14.

[18] ZAFARI, A., GHASEMI, H. M. and MAHMUDI, R. An investigation on the tribological behavior of AZ91 and AZ91 + 3 wt\% RE magnesium alloys at elevated temperatures. Materials and Design. 2014, vol. 54, pp. 544-552. 